Department of

Medical Biology and

Genetics, Cumhuriyet

University, Medical

Faculty, Sivas, Turkey

E F Percin

I Sezgin

Department of

Orthopaedics,

Cumhuriyet

University, Medical

Faculty, Sivas, Turkey

$S$ Percin

Department of

Radiodiagnostics,

Cumburiyet

University, Medical

Faculty, Sivas, Turkey

H Egilmez

DNA/Cell Bank and

Gene Research

Laboratory

(TUBITAK),

Hacettepe University,

Medical Faculty, Child

Health Institute,

Sihhiye 06100, Ankara,

Turkey

F Ozbas

A N Akarsu

Correspondence to:

Dr Akarsu.

Received 30 October 1997 Revised version accepted for publication 23 February 1998

\title{
Mesoaxial complete syndactyly and synostosis with hypoplastic thumbs: an unusual combination or homozygous expression of syndactyly type I?
}

E Ferda Percin, Sitki Percin, Hulusi Egilmez, Ilhan Sezgin, Filiz Ozbas, A Nurten Akarsu氶

\section{Abstract}

Syndactyly type $I$ is an autosomal dominant condition with complete or partial webbing between the third and fourth fingers or the second and third toes or both. We report here a previously undescribed phenotype of severe mesoaxial syndactyly and synostosis in patients born to affected parents. The characteristic features of these severe cases are (1) complete syndactyly and synostosis of the third and fourth fingers; (2) severe bone reduction in the proximal phalanges of the same fingers; (3) hypoplasia of the thumbs and halluces; (4) aplasia/hypoplasia of the middle phalanges of the second and fifth fingers; and (5) complete or partial soft tissue syndactyly of the toes. We report on three offspring with this phenotype from two different branches of a syndactyly type I family, suggesting that they may be homozygous for this condition. SSCP and linkage analysis indicated that neither
HOXD13 nor other relevant genes in the chromosome 2 q31 region was responsibłe for this phenotype.

$(\mathcal{F}$ Med Genet 1998;35:868-874)

Keywords: syndactyly type I; HOXD13; chromoso $\overrightarrow{\overrightarrow{m e j}}$ 2q31; homozygous phenotype

Isolated syndactyly is one of the most common congenital malformations affecting the han or feet or both. To date, many attempts hage been made to classify isolated syndactylies, bat none of them have covered all the types of syndactyly reported so far. According to the most widely used classification, isolated syndactylifs have at least five forms, all being inherited as autosomal dominant trait with variable expressivity and complete penetrance. ${ }^{1}$

In this classification, type I syndactypy (zygodactyly), which comprises complete \&r partial webbing between the third and fourth fingers or the second and third toes or both, as the most common form. Sometimes only the

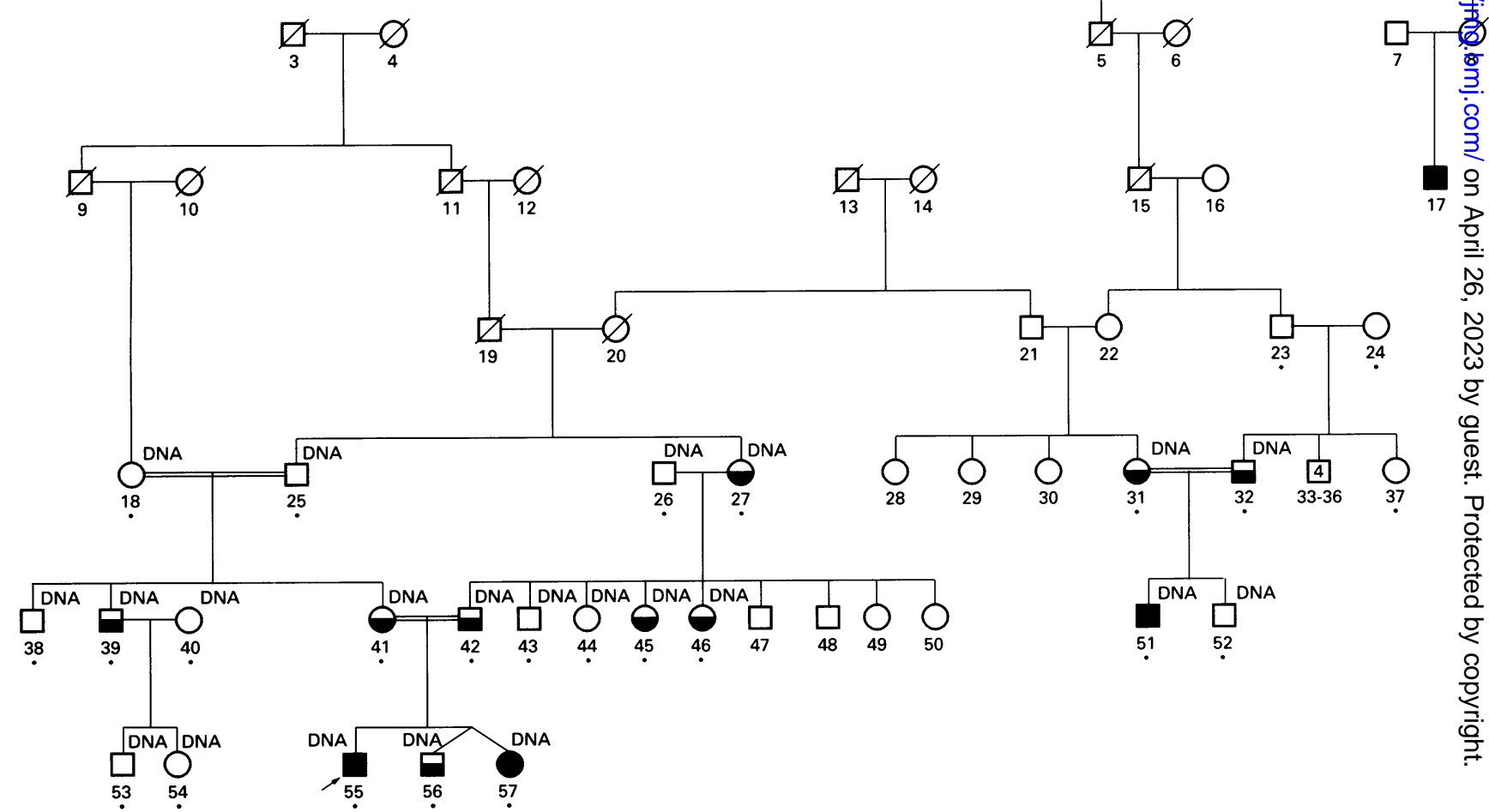

Figure 1 The large six generation Turkish syndactyly type I pedigree. Solid symbols are severely affected cases (homozygous?) and half shaded symbols are affected persons with only soft tissue syndactyly between the second and third toes. DNA $D N A$ available. Asterisks below symbols indicate that they had been examined. 


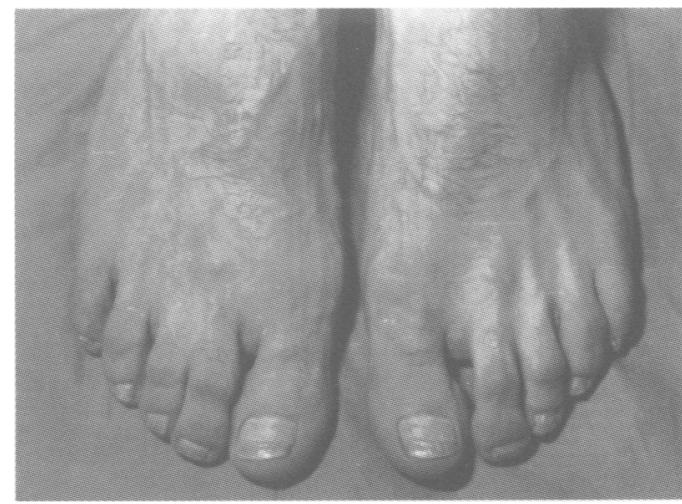

Figure 2 Subject 42 in fig 1 is an example of heterozygous syndactyly type I. Partial soft tissue syndactyly is present on the left and the right foot is also mildly affected.

hands are affected and sometimes only the feet. Type II syndactyly (synpolydactyly) shows various degrees of duplication along with syndactyly of the third and fourth fingers and fourth and fifth toes. Type III syndactyly is complete or partial webbing between the fourth and fifth fingers. Complete syndactyly of all fingers is classified as type IV syndactyly. The only type associated with metacarpal and metatarsal synostosis is type $\mathrm{V}$ syndactyly. In the latter, the abnormality usually affects the fourth and fifth fingers and toes and occasionally the third and fourth fingers and toes.

More recently, Winter and Tickle ${ }^{2}$ have proposed an alternative embryological classification of the syndactylies mainly based on the fact that the pattern formation is normal or abnormal. ${ }^{2}$ Although the genetic background of isolated syndactyly is clear, the gene(s) involved have not been identified, except for type II syndactyly (synpolydactyly). The expansion of alanine in the HOXD13 gene was found to be responsible for the synpolydactyly phenotype. $^{34}$

Here we report another example of mesoaxial deformity which appears with an unusual combination of complete syndactyly of the second to fourth fingers and toes, hypoplastic thumbs and halluces, and mesoaxial synostosis in at least three affected members of a large syndactyly type I family.

\section{Materials and methods}

The family in this study was from Sivas, Turkey. The pedigree consists of a total of 57 people of whom 13 are affected in seven generations (fig 1). Seventeen family members had already died by the time of the study. Twenty-four family members (12 affected) were examined by one of us (FP, SP, or HE). Radiographic evaluation was performed in five affected cases. Systemic evaluation, routine laboratory tests, abdominal ultrasonography, echography, and $x$ ray examination of the vertebral column were performed only for two sibs (subjects 55 and 57 in fig 1) who are severely affected with complete syndactlyly and synostosis. A total of 22 blood samples were obtained and DNA was extracted from relevant family members for molecular evaluation. SSCP analysis ${ }^{5}$ was performed to check point mutations in the HOXD13 coding region. Primers and amplification conditions were as previously reported. ${ }^{4}$ Amplified products were also separated on a $6 \%$ polyacrylamide gel for quick detection of potential size differences between affected and normal cases. The family was also tested for linkage to the chromosome $2 \mathrm{q} 31$ region where the synpolydactyly (SPD) gene has been mapped. ${ }^{6}$ Tightly linked DNA markers, D2S1238, D2S2307, and D2S2314, were used for linkage and haplotype analysis. Two point linkage was performed using the MLINK component of the LINKAGE package (Fastlink version 2.20) under the assumption of both autosomal dominant and autosomal recessive modes of inheritance with full penetrance.

Table 1 Physical findings of the three severely affected cases

\begin{tabular}{ll}
\hline Case & Hands \\
\hline $1 \quad$ Four fingers on both hands \\
Hypoplasia of thumbs \\
Complete syndactyly between 2nd and 3rd fingers on left \\
Partial syndactyly between 2nd and 3rd fingers on right \\
Complete syndactyly between 3rd and 4th fingers \\
Distal structures of 4th finger not palpable in the \\
synostotic complex \\
Flexion contracture of the 5th fingers \\
Bilateral simian line \\
Four fingers on both hands \\
Hypoplasia of thumbs \\
Complete syndactyly between 3rd and 4th fingers \\
Distal structures of 4th finger not palpable in the synostotic \\
complex \\
Flexion contracture of the 3rd finger on the right \\
Mild syndactyly between 2 nd and 3rd fingers on the left \\
Clinodactyly of 5th fingers \\
Bilateral simian line \\
Four fingers on both hands \\
Bilateral hypoplasia of 2nd fingers \\
Complete syndactyly between 3rd and 4th fingers \\
Hypoplastic nails on postaxial fingers \\
Four flexion lines on synostotic complex between 3rd and \\
4th fingers whereas only one flexion line on 2nd and 5th \\
fingers (fig 5C) \\
Clinodactyly of 5th fingers
\end{tabular}

Feet

Metatarsal varus and valgus deviation of toes Enlarged 1st and 2nd toes

Complete syndactyly between 2 nd and 3rd, partia syndactyly between 1 st and 2 nd toes on the right Complete syndactyly between 4 th and 5 th toes on the left Clinodactyly of 4th and 5 th toes on the right and 3rd, 4th, and 5 th toes on the left

Enlarged 1st and 2nd toes

Complete syndactyly between 2 nd and 3rd toes on the left Mild syndactyly between 2nd and 3rd toes on the right

Clinodactyly of 3 rd and 4 th toes on the right and 4th and 5th toes on the left

Small and broad halluces

Bilateral syndactyly between 2 nd and 3rd toes

Hypoplastic nails of big toes 
Table 2 Radiographic findings in the hands and feet of the three cases

\begin{tabular}{|c|c|c|c|c|c|}
\hline & & \multicolumn{2}{|l|}{ Case 1 (DOB 17.3.93) } & \multicolumn{2}{|l|}{ Case 2 (DOB 1.2.94) } \\
\hline & & Right & Left & Right & $\frac{3}{0}$ \\
\hline \multicolumn{2}{|l|}{ Hands } & & & & 2 \\
\hline \multicolumn{2}{|l|}{ Radius } & $\mathbf{N}$ & $\mathrm{N}$ & $\mathrm{N}$ & ค \\
\hline \multirow{2}{*}{\multicolumn{2}{|c|}{$\begin{array}{l}\text { Ulna } \\
\text { Capitate }\end{array}$}} & $\mathrm{N}$ & $\mathrm{N}$ & $\mathrm{N}$ & $\frac{\mathrm{d}}{\overrightarrow{0}}$ \\
\hline & & + & + & + & 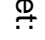 \\
\hline \multicolumn{2}{|l|}{ Hamate } & + & + & + & $\overrightarrow{\overline{\vec{\omega}}}$ \\
\hline \multirow{2}{*}{\multicolumn{2}{|c|}{ Trapezoid }} & + & + & -- & $\stackrel{7}{0}$ \\
\hline & $1 \mathrm{st}$ & Hypoplasia & Hypoplasia & Hypoplasia & 읃 \\
\hline & 2nd & & & $\mathrm{N}$ & $\overline{\underline{\sigma}}$ \\
\hline & $3 \mathrm{rd}$ & (Distal fusion between 3rd and 4th) & (Distal fusion between $3 \mathrm{rd}$ and $4 \mathrm{th}$ ) & Hyperplasia & $\overline{\bar{S}}$ \\
\hline & 4th & & & $\mathrm{N}$ & $\overrightarrow{\mathbb{D}}$ \\
\hline & 5th & $\mathbf{N}$ & $\mathbf{N}$ & $\mathbf{N}$ & อ \\
\hline \multirow[t]{5}{*}{ Proximal phalanges } & 1 st & Hypoplasia & Hypoplasia & Hypoplasia & ڤు \\
\hline & 2nd & & $\mathrm{N}$ & Deformed & $\rightarrow$ \\
\hline & $3 \mathrm{rd}$ & $\begin{array}{l}\text { (Severe hypoplasia, deformation in } 3 \text { rd } \\
\text { and } 4 \text { th) }\end{array}$ & $\begin{array}{l}\text { Severe hypoplasia (Hypoplasia, } \\
\text { deformation) }\end{array}$ & $\begin{array}{l}\text { (Complete synostosis between 3rd a } \\
\text { 4th) }\end{array}$ & $\stackrel{\bar{P}}{\overrightarrow{1}}$ \\
\hline & 4th & & & & $\vec{\omega}$ \\
\hline & 5th & Hypertrophy & Hypertrophy & $\mathrm{N}$ & قี่ \\
\hline \multirow[t]{5}{*}{ Middle phalanges } & $1 \mathrm{st}$ & -- & -- & - & $\omega$ \\
\hline & 2nd & Aplasia & Aplasia & Aplasia & G \\
\hline & $3 \mathrm{rd}$ & (Complete synostosis between $3 \mathrm{rd}$ and & (Complete synostosis between $3 \mathrm{rd}$ and & (Complete synostosis between $3 \mathrm{rd}$ & nd \\
\hline & 4th & 4th) & 4th) & 4 th) & க \\
\hline & 5 th & (Hypoplasia, deformation) & (Hypoplasia, deformation) & (Hypoplasia, deformation) & $\infty$ \\
\hline \multirow[t]{5}{*}{ Distal phalanges } & $1 \mathrm{st}$ & Hypoplasia & Hypoplasia & Hypoplasia & 윽 \\
\hline & 2nd & Hypoplasia & Hypoplasia & (Hypoplasia, deformation) & 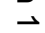 \\
\hline & 3 rd & $\begin{array}{l}\text { (Hypoplasia, complete synostosis } \\
\text { between 3rd and } 4 \text { th) }\end{array}$ & $\begin{array}{l}\text { (Hypoplasia, complete synostosis } \\
\text { between } 3 \text { rd and } 4 \text { th) }\end{array}$ & $\begin{array}{l}\text { (Hypoplasia, complete synostosis } \\
\text { between 3rd and 4th) }\end{array}$ & ९ \\
\hline & 4th & & & & 응 \\
\hline & 5th & $\mathbf{N}$ & $\mathbf{N}$ & $\mathbf{N}$ & ర్ \\
\hline \multicolumn{6}{|l|}{ Feet } \\
\hline \multicolumn{2}{|l|}{ Tibia } & $\mathbf{N}$ & $\mathbf{N}$ & $\mathbf{N}$ & $\overrightarrow{0}$ \\
\hline \multicolumn{2}{|l|}{ Fibula } & $\mathbf{N}$ & $\mathbf{N}$ & $\mathbf{N}$ & ق \\
\hline \multicolumn{2}{|l|}{ Talus } & $\mathrm{N}$ & $\mathbf{N}$ & $\mathrm{N}$ & \\
\hline \multicolumn{2}{|l|}{ Calcaneus } & $\mathrm{N}$ & $\mathbf{N}$ & $\mathrm{N}$ & $\oslash$ \\
\hline \multicolumn{2}{|l|}{ Navicular } & $\mathbf{N}$ & Hypoplasia & Hypoplasia & O \\
\hline \multirow[t]{3}{*}{ Cuneiform } & I & $\mathbf{N}$ & Hypoplasia & $\mathrm{N}$ & 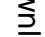 \\
\hline & II & $\mathbf{N}$ & Hypoplasia & $\mathbf{N}$ & $\overline{\bar{O}}$ \\
\hline & III & $\mathrm{N}$ & $\mathrm{N}$ & $\mathrm{N}$ & ฉి \\
\hline Cuboid & & $\mathrm{N}$ & $\mathrm{N}$ & $\mathrm{N}$ & D \\
\hline Metatarsal & $1 \mathrm{st}$ & $\begin{array}{l}\text { Hypoplasia of } 1 \text { st toe, varus deformity in } \\
\text { all metatarsals }\end{array}$ & $\begin{array}{l}\text { Hypoplasia of } 1 \text { st toe, varus deformity in } \\
\text { all metatarsals }\end{array}$ & Varus deformity in all metatarsals & $\stackrel{2}{\stackrel{2}{0}}$ \\
\hline & 2nd & & & & 3 \\
\hline & 3 rd & & & & 戸 \\
\hline & $\begin{array}{l}\text { 4th } \\
\text { 5th }\end{array}$ & & & & 营 \\
\hline Proximal phalanges & $1 \mathrm{st}$ & Deformed & Hypoplasic, deformed & $\mathrm{N}$ & $\overline{\widehat{z}}$ \\
\hline & 2nd & $\mathrm{N}$ & $\mathrm{N}$ & $\mathrm{N}$ & قี \\
\hline & $3 \mathrm{rd}$ & $\mathbf{N}$ & $\mathrm{N}$ & $\mathrm{N}$ & $\dot{\sigma}$ \\
\hline & 4th & $\mathrm{N}$ & $\mathrm{N}$ & $\mathrm{N}$ & 3 \\
\hline & 5 th & $\mathrm{N}$ & $\mathrm{N}$ & $\mathrm{N}$ & בְ. \\
\hline Middle phalanges & 2nd & $\mathrm{N}$ & Hypoplasia & $\mathrm{N}$ & อุ \\
\hline & $3 \mathrm{rd}$ & $\mathrm{N}$ & $\mathbf{N}$ & $\mathrm{N}$ & 3 \\
\hline & 4 th & $\mathrm{N}$ & $\mathrm{N}$ & $\mathrm{N}$ & 2 \\
\hline & 5 th & Aplasia & $\mathrm{N}$ & $\mathrm{N}$ & 윽 \\
\hline Distal phalanges & $1 \mathrm{st}$ & $\mathrm{N}$ & $\mathbf{N}$ & $\mathbf{N}$ & $D$ \\
\hline & 2 nd & Aplasia & $\mathrm{N}$ & $\mathrm{N}$ & 음 \\
\hline & $3 \mathrm{rd}$ & $\mathrm{N}$ & $\mathrm{N}$ & $\mathrm{N}$ & 三. \\
\hline & 4th & $\mathbf{N}$ & $\mathrm{N}$ & $\mathbf{N}$ & N \\
\hline & 5 th & Aplasia & Aplasia & $\mathrm{N}$ & (1) \\
\hline
\end{tabular}

\section{Results}

CLINICAL FINDINGS

Two sibs with severe syndactyly were diagnosed in the Department of Orthopaedics at Cumhuriyet University in Sivas, Turkey. The parents of the affected children were consanguineous (fig 1) and found to be affected with soft tissue syndactyly between the second and third toes (fig 2). Neither physical examination nor $x$ ray evaluation showed any abnormality in the hands of either parent. Dermatoglyphic changes in the hands, especially the absence of triradii at the base of the fingers (zygodactyly), can be a sign of involvement of the hands. However, the dermatoglyphics were normal in the hands of the parents of the affected children. Pedigree analysis showed seven more subjects with similar soft tissue syndactyly their toes with autosomal dominant inher ance with reduced penetrance and variab expressivity.

The other two cases (subjects 17 and 5 t5) with a more severe form of syndactyly we similar to the probands. The parents of subje 51 were consanguineous and had second ang third toe syndactyly. However, accurate information about consanguinuity and compleqe physical examination could not be obtained far subject 17, whose hands and feet are severes. affected, since the entire branch of the family moved to Germany many years ago.

The comparative physical and $x$ ray findings of cases with severe syndactyly are summarised in tables 1 and 2 . 
Table 2 Continued

\begin{tabular}{|c|c|c|}
\hline \multirow[b]{2}{*}{ Left } & \multicolumn{2}{|l|}{ Case 3 (DOB 1.1.91) } \\
\hline & Right & Left \\
\hline $\begin{array}{l}N \\
N \\
+\end{array}$ & $\begin{array}{l}\mathrm{N} \\
\mathrm{N} \\
\text { Carpal bones complete } \\
\text { except scaphoid bone }\end{array}$ & $\begin{array}{l}\mathbf{N} \\
\mathbf{N} \\
\text { Carpal bones complete }\end{array}$ \\
\hline \multicolumn{3}{|c|}{ 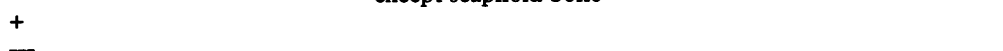 } \\
\hline $\begin{array}{l}\overline{H y p o p l a s i a} \\
\mathrm{~N} \\
\text { Hyperplasia } \\
\mathrm{N} \\
\mathrm{N} \\
\text { Hypoplasia } \\
\mathrm{N} \\
\text { Severe hypoplasia }\end{array}$ & $\begin{array}{l}\text { Minimal hypoplasia } \\
\mathbf{N} \\
\mathbf{N} \\
\mathbf{N} \\
\mathbf{N} \\
\mathbf{N} \\
\mathbf{N} \\
\text { (Complete synostosis } \\
\text { between 3rd and 4th) }\end{array}$ & $\begin{array}{l}\text { Minimal hypoplasia } \\
\mathrm{N} \\
\mathrm{N} \\
\mathrm{N} \\
\mathrm{N} \\
\mathrm{N} \\
\mathrm{N} \\
\text { (Complete synostosis } \\
\text { between 3rd and 4th) }\end{array}$ \\
\hline \multicolumn{3}{|l|}{$\begin{array}{l}\text { Deformation and synostosis } \\
\text { with } 3 \text { rd }\end{array}$} \\
\hline $\mathbf{N}$ & $\mathbf{N}$ & $\mathbf{N}$ \\
\hline- & - & - \\
\hline $\begin{array}{l}\text { Aplasia } \\
\text { N }\end{array}$ & $\begin{array}{l}\text { Severe hypoplasia } \\
\text { (Complete synostosis } \\
\text { between 3rd and 4th) }\end{array}$ & $\begin{array}{l}\text { Severe hypoplasia } \\
\text { (Complete synostosis } \\
\text { between 3rd and 4th) }\end{array}$ \\
\hline $\begin{array}{l}\text { Aplasia } \\
\text { (Hypoplasia, deformation) } \\
\text { Hypoplasia } \\
\text { (Hypoplasia, deformation) } \\
\text { (Hypoplasia, complete } \\
\text { synostosis between 3rd and } \\
\text { 4th) }\end{array}$ & $\begin{array}{l}\text { Severe hypoplasia } \\
\text { N } \\
\text { Severe hypoplasia } \\
\text { (Hypoplasia, complete } \\
\text { synostosis between 3rd and } \\
\text { 4th) }\end{array}$ & $\begin{array}{l}\text { Severe hypoplasia } \\
\text { N } \\
\text { Severe hypoplasia } \\
\text { (Hypoplasia, complete } \\
\text { synostosis between 3rd and } \\
\text { 4th) }\end{array}$ \\
\hline $\mathbf{N}$ & Hypoplasia & Hypoplasia \\
\hline $\begin{array}{l}\mathbf{N} \\
\mathbf{N} \\
\mathbf{N} \\
\mathbf{N} \\
\mathbf{N} \\
\mathbf{N} \\
\mathbf{N} \\
\mathbf{N} \\
\mathbf{N} \\
\text { Varus deformity in all } \\
\quad \text { metatarsals }\end{array}$ & $\begin{array}{l}\mathbf{N} \\
\mathbf{N} \\
\mathbf{N} \\
\mathbf{N} \\
\mathbf{N} \\
\mathbf{N} \\
\mathbf{N} \\
\mathbf{N} \\
\mathbf{N} \\
\text { Varus deformity in all } \\
\text { metatarsals }\end{array}$ & $\begin{array}{l}\mathbf{N} \\
\mathbf{N} \\
\mathbf{N} \\
\mathbf{N} \\
\mathbf{N} \\
\mathbf{N} \\
\mathbf{N} \\
\mathbf{N} \\
\mathbf{N} \\
\text { Varus deformity in all } \\
\text { metatarsals }\end{array}$ \\
\hline $\begin{array}{l}\mathbf{N} \\
\mathbf{N} \\
\mathbf{N} \\
\mathbf{N} \\
\mathbf{N} \\
\mathbf{N} \\
\mathbf{N} \\
\mathbf{N} \\
\mathbf{N} \\
\mathbf{N} \\
\mathbf{N} \\
\mathbf{N} \\
\mathbf{N} \\
\mathrm{N}\end{array}$ & $\begin{array}{l}\mathrm{N} \\
\mathrm{N} \\
\mathrm{N} \\
\mathrm{N} \\
\mathrm{N} \\
\text { Hypoplasia } \\
\text { Aplasia } \\
\text { Aplasia } \\
\text { Aplasia } \\
\text { Hypoplasia } \\
\text { Hypoplasia } \\
\text { Hypoplasia } \\
\text { Hypoplasia } \\
\text { Hypoplasia }\end{array}$ & $\begin{array}{l}\mathrm{N} \\
\mathrm{N} \\
\mathrm{N} \\
\mathrm{N} \\
\mathrm{N} \\
\text { Hypoplasia } \\
\text { Aplasia } \\
\text { Aplasia } \\
\text { Aplasia } \\
\text { Hypoplasia } \\
\text { Hypoplasia } \\
\text { Hypoplasia } \\
\text { Hypoplasia } \\
\text { Hypoplasia }\end{array}$ \\
\hline
\end{tabular}

Case 1 (subject 55, fig 1)

The proband is a 4 year old male with normal mental and physical development. He had four fingers on each hand with partial or complete syndactyly involving all four extremities (fig 3A, B). Both hands displayed soft tissue syndactyly mainly between the second and third fingers. The fourth fingers were not distinguishable individually; only small, dysmorphic, and rudimentary bone particles were palpable within the mass next to the third finger bilaterally. The thumbs were short and hypoplastic. The fifth finger had a flexion contracture deformity with clinodactyly on both sides. The nails were normal. A simian line was observed bilaterally.

$X$ rays of the hands showed a similar picture on both sides (fig 3C). Partial
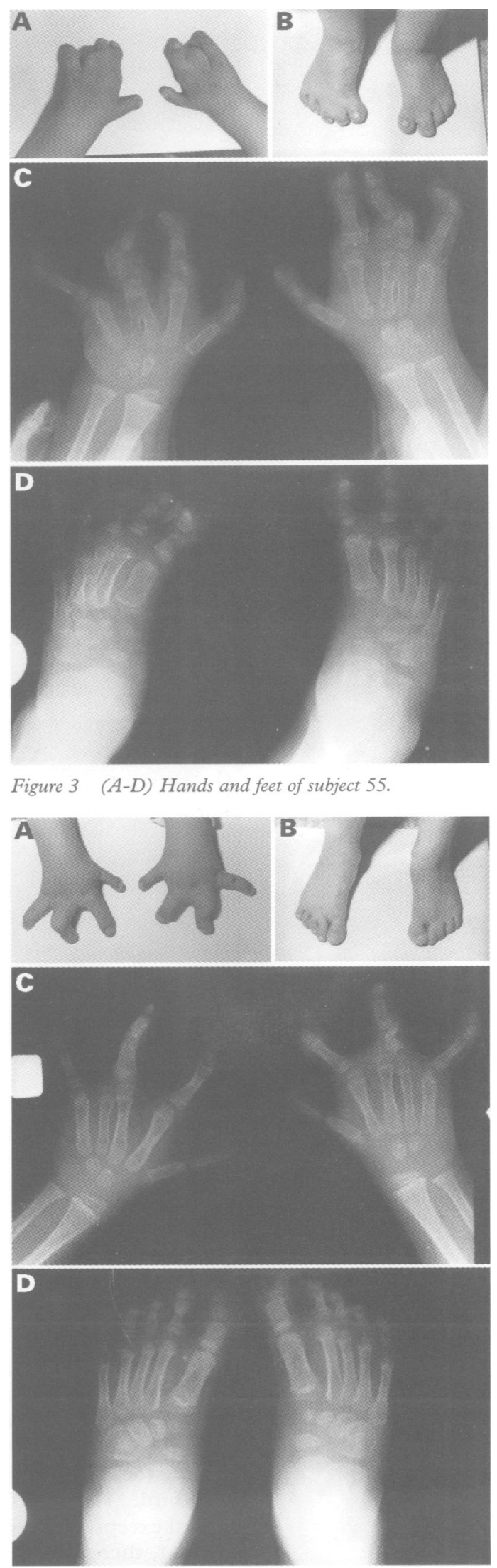

figure 4 (A-D) Hands and feet of subject 57.

synostosis of the third and fourth metacarpal bones along with a severely hypoplastic biphalangeal thumb were present. The middle phalanges were absent in the second fingers and hypoplastic in the fifth fingers. The distal phalanges of all fingers were hypoplastic and dysmorphic. Normal tubular 

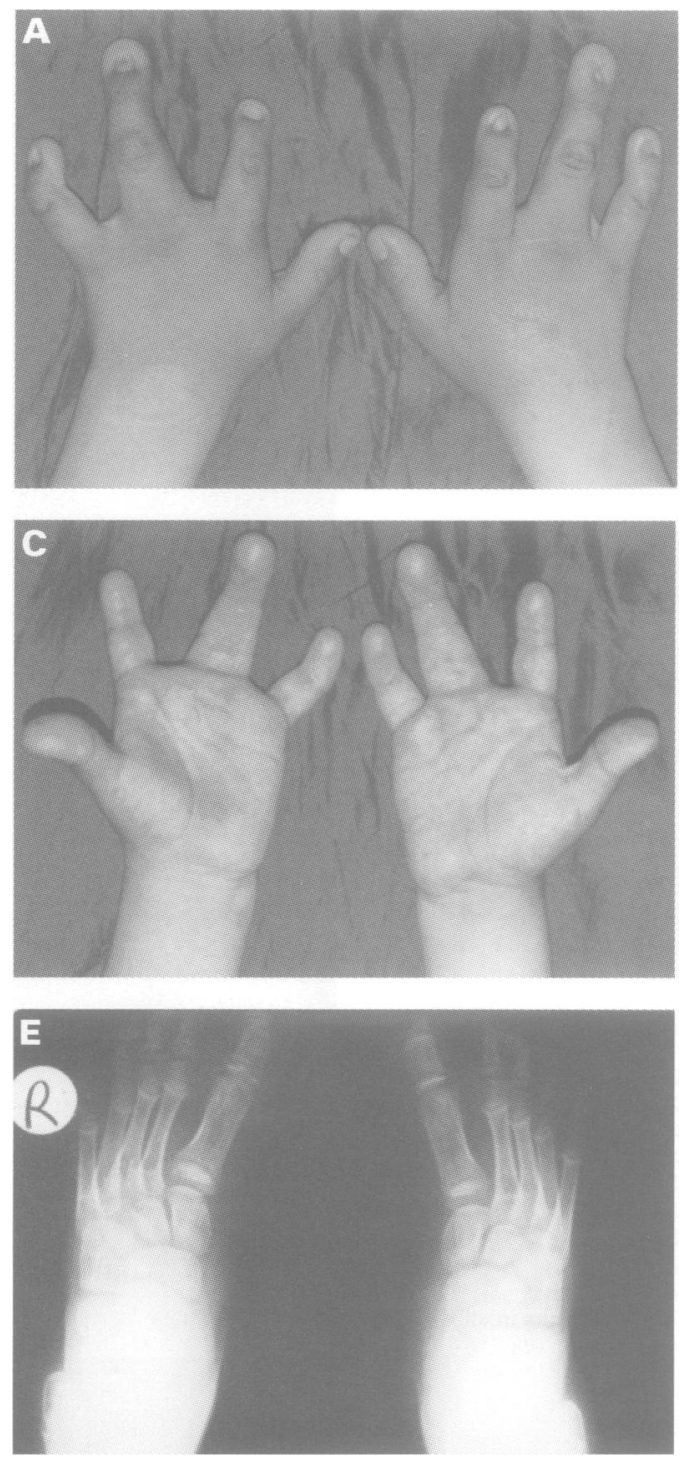

shapes were lost in the proximal phalanges of the synostotic complex and replaced by some cuboid structures owing to severe bone retardation. Complete synostosis of the third and fourth fingers was the main finding in the distal part of this complex. Bone age was compatible with that of a 3 year old child.

The feet showed varus deformity in the metatarsal region but all toes were in the valgus position (fig 3B). The feet were dissimilar apart from short and enlarged first and second toes. On the right foot the first three toes were webbed. Syndactyly was partial between the first two toes but complete between the second and third. The fourth and fifth toes were normal except for clinodactyly in both. On the left foot, there was complete syndactyly only between the fourth and fifth toes. Clinodactyly was also present in the last three toes. $X$ rays of the feet showed severe growth retardation of the tarsal bones especially the navicular and first and second cuneiform bones in the left foot. The proximal and distal phalanges of the big toes were found to be hypoplastic and deformed on both sides with variable severity (fig 3D).
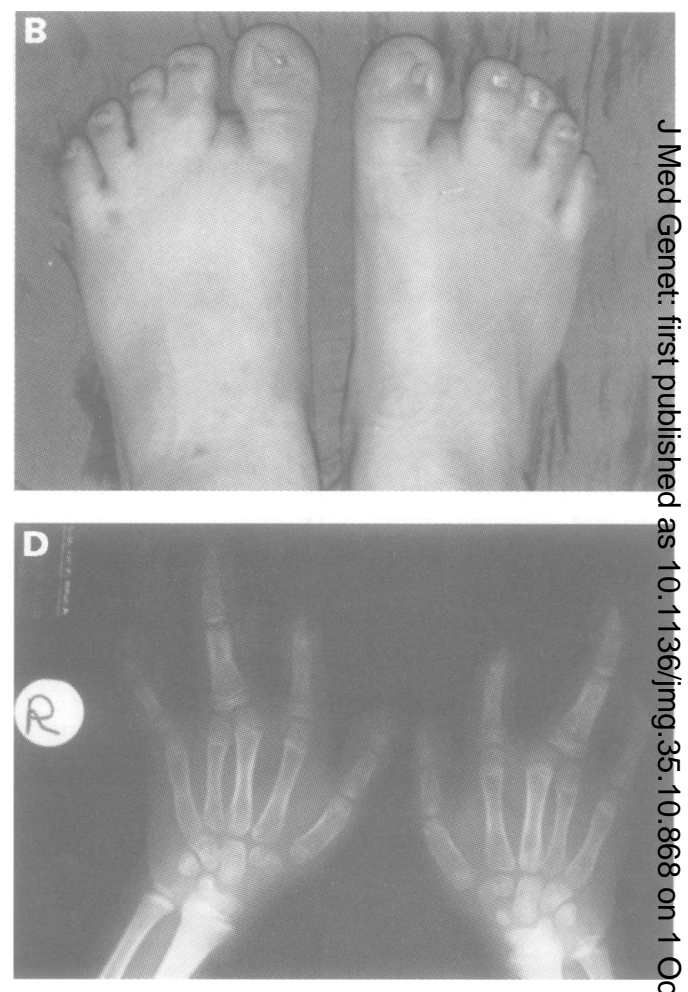

Figure 5 (A-E) Hands and feet of subject 51. (C) Note four flexion lines on synostotic complex.

Case 2 (subject 57, fig 1)

The proband's 2 year old sister had four finger on each hand. Her psychomotor developmen was normal. The phenotypic appearance was quite similar to the proband's except for come plete syndactyly between the second and third fingers (fig 4A). Complete syndactyly mainit. involved the third and fourth fingers and therev was hypoplasia of both thumbs. $X$ rays of the hands showed hypoplasia of the first metacar pal bones (fig 4C). Like the proband, there was symmetrical aplasia of the middle phalanx severe hypoplasia of the second fingers, and clinodactyly of the fifth fingers. The norma tubular shape was lost in the proximal phalani of the third finger and replaced by twō deformed, shapeless bony structures. Comb pared to the proband the phenotypic expres $\frac{1}{8}$ sion was less severe in the feet, the prominent manifestation being soft tissue syndactyl between the second and third toes on the le (fig 4B, D).

She had a dizygotic male twin sib (fig 1 , sub? ject 56). He had mild soft tissue syndactyly in the feet between the second and third and fourth and fifth toes. The hands were normal. The phenotype of case 3 (fig 1 , subject 51 , 

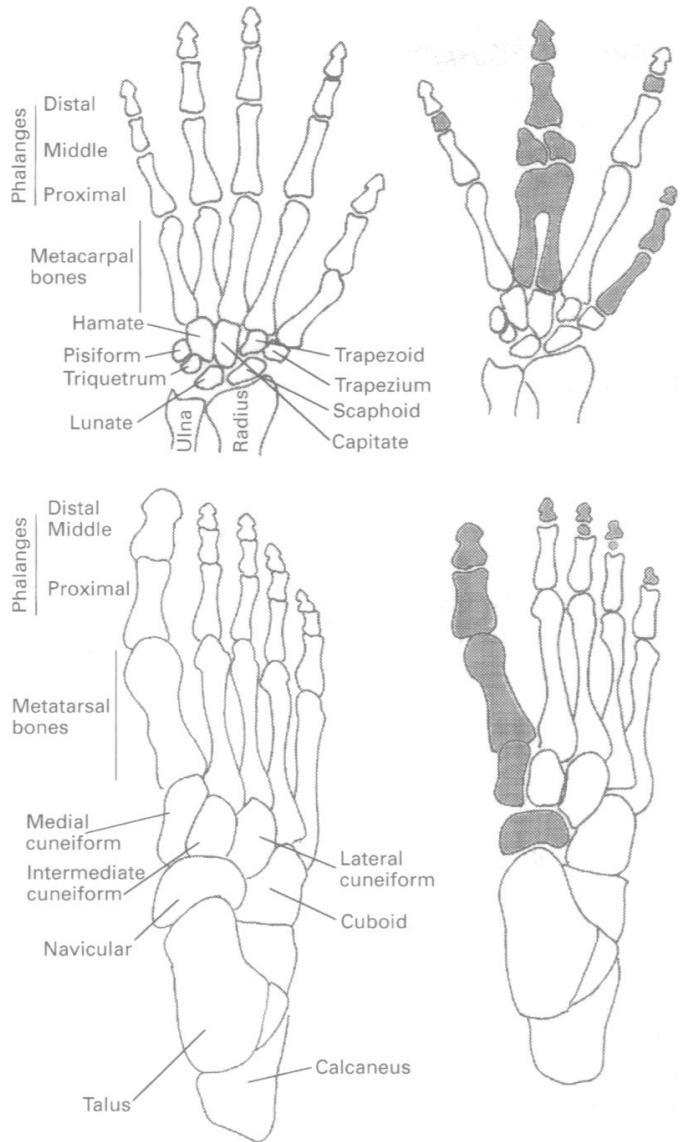

Figure 6 Illustration of bone structures in complete mesoaxial syndactyly of both hands and feet. A normal hand and foot are shown on the left. The filled structures represent the affected bones. The middle phalanges are usually and randomly lost whereas there is hypoplasia of the distal phalanges in the feet. Note metacarpal synostosis. Hypoplasia of the first cuneiform and navicular bone is observed in only one case (subject 55, see text).

fig 5A-E, tables 1 and 2) was similar to those of the above mentioned cases except for the severe hypoplasia of the thumbs.

The abnormalities of the severely affected cases are illustrated in fig 6.

\section{MOLECULAR STUDIES}

Previously it has been shown that a gain of function type mutation in the upstream exon of HOXD13 produced the synpolydactyly phenotype. ${ }^{34}$ In synpolydactyly, the abnormality mainly involves the mesoaxial line, starting at the metacarpal level, and does not change the proximal-distal and anterior-posterior pattern except for duplication of the third finger and the fifth toes. ${ }^{78}$ Generally, similar features also exist in the phenotype of the cases with severe syndactyly, with the exception of the

Table 3 Lod scores between syndactyly type I and DNA markers from chromosome $2 q 31$ (synpolydactyly region) assuming autosomal dominant mode of inheritance. The respective map order of the markers and the position of candidate genes are centromere D2S1238-

DLX1/DLX2/EVX2/D2S2307-D2S2314/HOXD cluster-telomere. ${ }^{4}$ Approximate

distance between D2S1238 and HOXD cluster is $2.4 \mathrm{cM} .{ }^{4}$ Exclusion area was determined according to the recombination fraction (cM) at which the lod score was $\leqslant-2$

Recombination fraction $(\theta)$

\begin{tabular}{llllllll} 
Marker & 0.001 & 0.05 & 0.10 & 0.20 & 0.30 & 0.40 & Exclusion (cM) \\
\hline D2S1238 & -7.50 & -2.34 & -1.43 & -0.59 & -0.20 & -0.03 & 6 \\
D2S2307 & -4.04 & -0.80 & -0.35 & -0.04 & 0.03 & 0.02 & 1 \\
D2S2314 & -9.42 & -2.77 & -1.71 & -0.81 & -0.41 & -0.18 & 8 \\
\hline
\end{tabular}

missing fourth finger instead of the duplication seen in synpolydactyly. Therefore, we considered that the possibility of a lack of function type mutation in the HOXD13 could produce this unique phenotype. However, we could not observe any changes in the HOXD13 coding region by means of SSCP analysis and size detection in polyacrylamide gels. On the other hand, the region harbouring HOXD13 has a number of genes each of which is closely related to limb development (for example, EVX2, DLX1, DLX2, etc). We performed linkage analysis to see if this syndactyly type I family is also linked to this region. Under the assumption of autosomal dominant inheritance, negative lod scores were obtained with DNA markers D2S1238, D2S2307, and D2S2314 from the 2q31 region (table 3). The most informative DNA marker, D2S2314, excluded the disease phenotype for at least 8 cM outside the critical region (exclusion area $=0.08$ at $Z \leqslant-2$ ). The same data were evaluated assuming autosomal recessive inheritance with full penetrance. Neither homozygosity nor shared haplotype for the entire region was observed in the affected cases.

\section{Discussion}

Here we present an unusual combination of mesoaxial complete syndactyly with hypoplasia of the thumbs and halluces in children born to two affected parents with type I syndactyly. Type I syndactyly is the most common form of syndactyly involving the third and fourth fingers as well as the second and third toes. Involvement of the feet only is common in type I. ${ }^{9}$ The family reported here has type I syndactyly with only involvement of the feet segregating in an autosomal dominant fashion in at least three generations.

We have identified two marriages between two affected people. These produced a total of five offspring, three of whom show a more severe phenotype. The characteristic findings in these subjects are: (1) complete syndactyly in the third and fourth fingers; (2) severe bone reduction in the proximal phalanges of the same fingers; (3) hypoplasia of the thumbs and halluces; (4) aplasia/hypoplasia of the middle phalanges of the second and fifth fingers; and (5) complete or partial soft tissue syndactyly of the toes. This is the first report of these findings in a type I syndactyly family and could represent the homozygous state. To the best of our knowledge, homozygosity for type 1 syndactyly has not been reported before. More severe expression is expected in autosomal dominant disorders and a number of examples have been published. These severe cases born to two affected parents are good candidates for homozygosity for type I syndactyly.

On the other hand, metacarpal synostosis seen in one affected case raises the possibility that these severe cases are type $\mathrm{V}$ syndactyly cosegregating in a type I syndactyly family. Type V syndactyly is the only type which includes metacarpal and metatarsal synostosis usually between the fourth and fifth digits in both hands and feet. ${ }^{1}$ Occasionally, synostosis is seen between the third and fourth digits. The 
mode of inheritance is autosomal dominant. In our family, only one sib is affected with synostosis. Additionally, none of the other family members has metacarpal or metatarsal synostosis, supporting autosomal dominant inheritance. Therefore, the possibility of these cases being a phenotypic variation of type $\mathrm{V}$ syndactyly is less likely.

Usually, these types of complex syndactyly are classified under different syndromes, for example, hand-foot-uterus (HFU) syndrome (OMIM 140000). Hypoplastic thumbs and halluces are one of the prominent features of hand-foot-uterus syndrome. In our cases, thumb and hallux hypoplasia is present, but there were no urinary tract or genital findings which are seen in HFU syndrome. Similarly, severe soft tissue syndactyly and the bone synostosis described in our cases are not characteristic features of HFU syndrome.

Autosomal recessive inheritance causing this unusual phenotype should also be considered owing to the highly inbred nature of the pedigree. The OMIM catalogue (http:// www3.ncbi.nlm.nih.gov/omim/) gives 82 entries for the autosomal recessive syndactylies. However, none of these are isolated entities nor do they show the characteristic features observed in our severe syndactyly cases. Therefore, the phenotype reported here with no associated abnormality appears to be a new entity, possibly representing homozygosity for type I syndactyly. On the other hand, webbing between the second and third toes is very frequent in the population and often found in spouses. One might expect that homozygosity is therefore not very rare in the general population. However, if genetic heterogeneity exists in syndactyly type I, the spouses with similar phenotypic manifestations could have a different non-allelic mutation. This would diminish the chance of observing many homozygous cases in the population. Since the familz reported here is highly inbred, both parents ar\& expected to share the same molecular abnor mality which could therefore produce homo zygous features of syndactyly type I.

Since the gene(s) for type I syndactyly ha灰 not yet been mapped, we could not test the homozygosity at a molecular level. Howeve our molecular studies indicate that neithe HOXD13 nor other relevant genes in th region are responsible for this phenotype.

The authors wish to thank the family members who participated in this study. We would like to express our deepest appreciation. to Dr Robin M Winter, Institute of Child Health, London, UKW for his comments and critical review of this manuscript before submission.

1 Temtamy SA, McKusick VA. The genetics of hand malfo mations. Birth Defects 1978;XIV(3):301-2. Winter RM, Tickle C. Syndactylies and polydactylies Hum Genet 1993;1:96-104.

3 Muragaki Y, Mundlos S, Upton J, Olsen BR. Altered growtb and branching patterns in synpolydactyly caused by mutations in HOXD13. Science 1996;272:548-51.

4 Akarsu AN, Stoilov I, Yýlmaz E, Saylý BS, Sarfarazi M. Genomic structure of HOXD13 gene: a nine polyalanine duplication causes syndactyly in two unrelated familie 0 Hum Mol Genet 1996;5:945-52.

5 Hayashi K. PCR-SSCP: a method for detection of mutations. GATA 1992;9:73-9.

6 Sarfarazi M, Akarsu AN, Sayly BS. Localization of the syre dactyly type II (synpolydactyly) locus to $2 \mathrm{q} 31$ region ando identification of tight linkage to HOXD8 intragenic identification of tight linkage to marker. Hum Mol Genet 1995;4:1453-8.

7 Sayli BS, Akarsu AN, Sayli U, Akhan O, Ceylaner Sarfarazi M. A large Turkish kindred with syndactyly typo II (synpolydactyly). 1. Field investigation, clinical and pedigree data. $\mathcal{F}$ Med Genet 1995;32:421-34.

8 Akarsu AN, Akhan O, Sayli BS, Sayli U, Baskaya 乞ै Sarfarazi $M$. A large Turkish kindred with syndactyly type II (synpolydactyly). 2. Homozygous phenotype? $\mathcal{f}$ Ment Genet 1995;32:435-41.

9 McKusick VA. Mendelian inheritance in man. 10th ed Baltimore: The Johns Hopkins University Press, 1992. 